\title{
Anatomia foliar de genótipos do gênero Desmanthus
}

\author{
Leaf anatomy in genotypes of Desmanthus genus \\ Anatomía foliar de genotipos del género Desmanthus
}

\section{Resumo}

Existem discrepâncias na literatura quanto a identificação de espécies do gênero Desmanthus. Objetivou-se caracterizar anatomicamente três genótipos que representam as espécies Desmanthus pernambucanus (7G, 50J) e D. virgatus (13AU). O material foi coletado no campo experimental da Unidade Acadêmica de Serra Talhada (UAST/UFRPE), na estação seca. Folhas de diferentes idades foram coletadas e fracionadas em pecíolo, nectário extrafloral, ráquis, peciólulo e foliólulo, seguindo-se o preparo das lâminas. A morfologia do pecíolo variou entre genótipos e folhas. O nectário extrafloral apresentou formato de cálice enquanto o peciólulo apresentou-se em aspecto de $\mathrm{U}$ em todos os genótipos estudados. Na ráquis, a morfologia do $7 \mathrm{G}$ e $50 \mathrm{~J}$ foi semelhante, em ambas as folhas com projeções superiores, enquanto o genótipo 13AU apresentou formato cilíndrico. O foliólulo apresentou-se com uma única camada de células epidérmicas e mesofilo dorsiventral, exceto nas folhas jovens do genótipo $7 \mathrm{G}$ e $50 \mathrm{~J}$. Foram observadas cavidades secretoras no tecido floemático em todas as frações estudadas, com exceção dos foliólulos. Ocorreram cristais prismáticos em todos os genótipos e frações estudadas. Existem características anatômicas e morfológicas que permitem a distinção entre as espécies estudadas.

Palavras-chave: Caatinga; Espécies; Fabaceae; Jureminha.

\begin{abstract}
There is a discrepancy in literature about the identification of species from Desmanthus genus. The aim was to characterize anatomically three genotypes representing Desmanthus pernambucanus (7G, 50J) and D. virgatus (13AU) species. The material was collected in experimental field of the Academic Unit of Serra Talhada (UAST/UFRPE) in dry season. Leaves of different ages were collected and fractionated into petiole, extrafloral nectary, rachis, petiolule and leaflet, following the slide preparation. Petiole morphology varied among genotypes and leaves studied. Extrafloral nectary is calyx-shaped whereas petiolule showed similar morphology in all genotypes. Rachis had similar morphology in $7 \mathrm{G}$ and $50 \mathrm{~J}$, for both leaves showing upper projections containing vascular bundles, whereas 13AU genotype showed a cylindrical shape. The leaflet showed a single layer of epidermal cells and dorsiventral mesophyll, except in young leaflets of $7 \mathrm{G}$ and $50 \mathrm{~J}$ genotypes. It was observed secretory cavities in
\end{abstract}


phloem at all fractions, except in the leaflets. There are anatomical and morphological features that may be useful to distinguish the studied species.

Keywords: Bundleflower; Caatinga; Fabaceae; Species.

\section{Resumen}

Existen discrepancias en la literatura con respecto a la identificación de especies del género Desmanthus. El objetivo fue caracterizar anatómicamente tres genotipos que representan las especies Desmanthus pernambucanus $(7 \mathrm{G}, 50 \mathrm{~J})$ y D. virgatus (13AU). El material fue recolectado en el campo experimental de la Unidad Académica Serra Talhada (UAST / UFRPE), en la época seca. Se recolectaron hojas de diferentes edades y se dividieron en pecíolo, nectario extrafloral, raquis, pecíolo y folíolo, seguido de preparación de la hoja. La morfología del pecíolo varió entre genotipos y hojas. El nectario extrafloral mostró forma de cáliz mientras que el peciolulo tenía forma de U en todos los genotipos estudiados. En el raquis, la morfología de $7 \mathrm{G}$ y $50 \mathrm{~J}$ fue similar, en ambas hojas con proyecciones superiores, mientras que el genotipo 13AU presentó forma cilíndrica. El foliolo presentaba una sola capa de células epidérmicas y mesófilo dorsiventral, a excepción de las hojas jóvenes de genotipo $7 \mathrm{G}$ y $50 \mathrm{~J}$. Se observaron cavidades secretoras en el tejido del floema en todas las fracciones estudiadas, excepto en los folíolos. Los cristales prismáticos se presentaron en todos los genotipos y fracciones estudiadas. Existen características anatómicas y morfológicas que permiten la distinción entre las especies estudiadas.

Palabras clave: Caatinga; Especies; Fabaceae; Jureminha.

\section{Introdução}

O clima semiárido ocorre em grande parte do Nordeste brasileiro, caracterizando-se pelas altas temperaturas médias anuais e baixos índices de precipitação pluvial e umidade relativa do ar. Esta combinação de fatores resulta em balanço hídrico negativo por quase todo o ano, favorecendo a ocorrência de uma vegetação xerófila, denominada Caatinga, a qual é o principal recurso forrageiro para os animais da região.

O bioma Caatinga possui uma grande biodiversidade florística, onde a família Fabaceae é a uma das mais expressivas. Inserido nessa família, o gênero Desmanthus vem se destacando por ter espécies nativas com potencial forrageiro, como a jureminha (D. pernambucanus (L.) Thellung), além de ter indivíduos mais conhecidos, como a D. virgatus (L.) Willd.

Apesar de pertencerem ao mesmo gênero, estas espécies possuem características morfológicas distintas tornando a identificação do gênero complexa. Devido as informações discrepantes na literatura, alguns estudos taxonômicos e moleculares foram realizados na tentativa de solucionar tais lacunas (Costa et al., 2017; Verloove \& Borges, 2018).

De acordo com Verloove e Borges (2018) é possível diferenciar a espécie D. pernambucanus da D. virgatus através de algumas características morfológicas como o hábito de crescimento ereto, movimentos nictinásticos onde as folhas ficam voltadas para baixo, folíolos ocorrendo de 2 a 4 pares, maior tamanho do pecíolo/nectário extrafloral e alongamento do hipocótilo.

Além destas características, os aspectos produtivos também diferem de acordo com estudo realizado por Calado et al. (2016) avaliando 5 genótipos do gênero Desmanthus. Os autores verificaram que o genótipo 7G (D. pernambucanus) teve a maior produção de forragem. Além deste, a segunda e terceira maior produção foi dos genótipos 50J (D. pernambucanus) e 13AU (D. virgatus), respectivamente, mostrando a adaptabilidade da espécie $D$. pernambucanus à condição semiárida.

Estas espécies apresentam atributos desejáveis para utilização na alimentação animal, como a boa produção de forragem, alto valor nutritivo, boa digestibilidade e baixa concentração de compostos anti-nutricionais (Muir \& Pitman, 1991). Porém, devido ao fato de a literatura muitas vezes se referir à $D$. pernambucanus como $D$. virgatus, conforme relatado por Verloove e Borges (2018), torna-se necessário investigar mais a fundo as razões pelas quais genótipos de uma mesma espécie apresentam diferenças produtivas e, também, quais as diferenças morfo-anatômicas existentes entre as duas espécies.

Muitas destas variações podem ser explicadas pelo estudo anatômico do vegetal, pois o arranjo espacial dos tecidos é fundamental para se compreender os mecanismos adaptativos de uma espécie em um dado ambiente (Ren et al., 2019). Além disso, o estudo anatômico tem grande importância quanto ao valor taxonômico, pois muitas vezes a distinção entre espécies ocorre por meio da presença de diferentes estruturas (Metcalfe \& Chalk, 1950). 
Como as plantas da região Semiárida passam por períodos prolongados de déficit hídrico, a água se torna um fator limitante para a realização das atividades fotossintéticas. Portanto, deve-se considerar as características do tecido vascular, por seu papel essencial no transporte de água (Brodersen et al., 2019), como também a presença de outros fatores adaptativos que atuem em conjunto assegurando a manutenção da fotossíntese. Assim, teve-se por objetivo caracterizar anatomicamente as folhas de D. pernambucanus e D. virgatus representados pelos genótipos 7G, 50J e $13 \mathrm{AU}$.

\section{Metodologia}

O campo experimental onde foram realizadas as coletas está localizado no município de Serra Talhada, Pernambuco (latitude $07^{\circ} 53^{\prime} 57^{\prime}$ 'S, longitude $38^{\circ} 18^{\prime} 09^{\prime}$ 'O), com classificação Köppen do tipo BSh, ou seja, semiárido, quente, com chuvas de verão, apresentando temperatura média anual de $25^{\circ} \mathrm{C}$ e precipitação média anual $<800 \mathrm{~mm}$ (Alvares et al., 2013).

Os valores de precipitação pluvial do local de estudo foram contabilizados no período de um ano até a data da coleta, que aconteceu no dia 14 de janeiro de 2017 (Figura 1). Os dados de precipitação pluvial durante o período experimental e da normal climatológica foram obtidos no banco de dados do Instituto Nacional de Meteorologia (INMET),

Figura 1. Precipitação pluvial (mm) no ano de 2016 e normal climatológica do município de Serra Talhada.

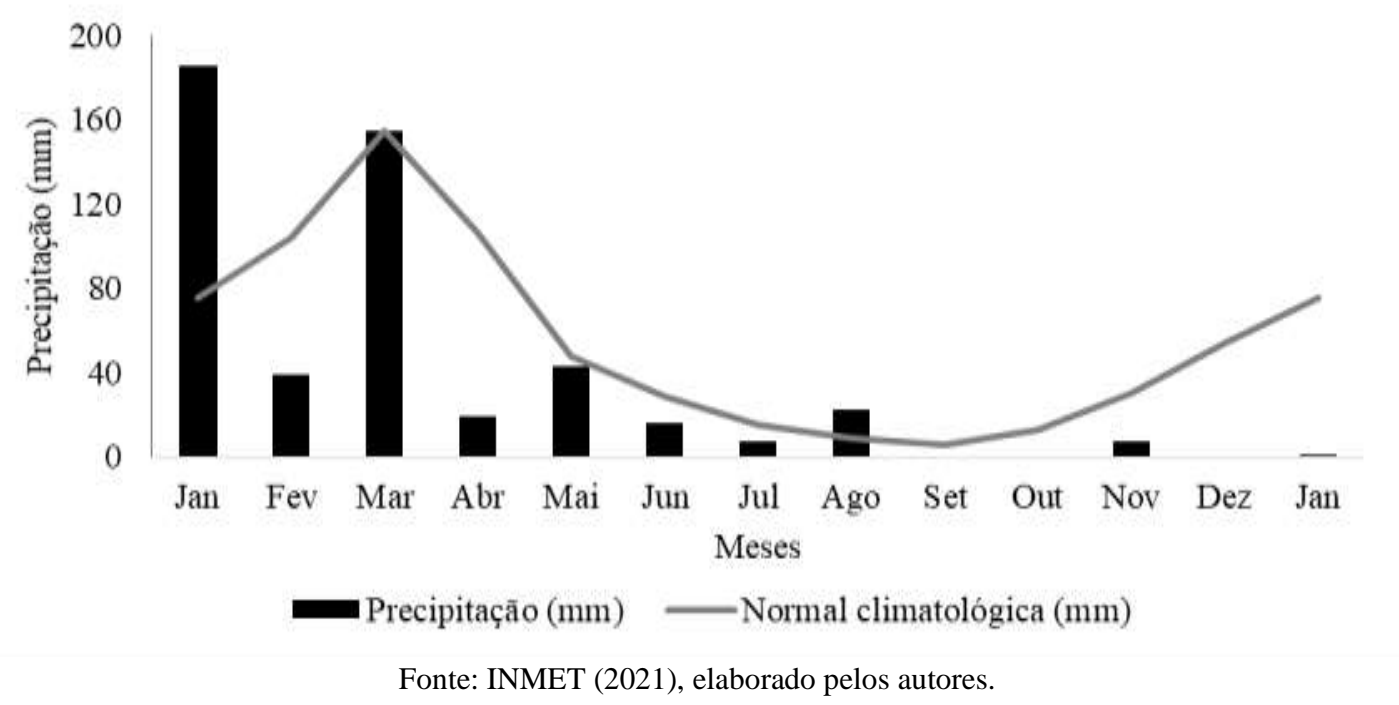

Os genótipos avaliados foram selecionados com base na sua produção de forragem, ou seja, o genótipo 7G (1002,06 $\mathrm{kg} \mathrm{MS} \mathrm{ha-1}), 50 \mathrm{~J}\left(771,31 \mathrm{~kg} \mathrm{MS} \mathrm{ha}^{-1}\right)$ e 13AU $\left(509,68 \mathrm{~kg} \mathrm{MS} \mathrm{ha}^{-1}\right)$. As coletas foram realizadas durante a época seca no campo experimental da Unidade Acadêmica de Serra Talhada - UAST, Universidade Federal Rural de Pernambuco - UFRPE. As folhas de Desmanthus spp. foram coletadas no sentido ápice-base do caule, selecionando-se as folhas do $1^{\circ}$ e $3^{\circ}$ nó de uma planta de cada genótipo. Com isso, distinguiu-se as idades em jovem e madura. A folha jovem (folha 1 ) localizava-se no $1^{\circ}$ nó, enquanto a folha mais expandida localizava-se no $3^{\circ}$ nó (folha 3 ). 
A coleta foi realizada no início da manhã e, por este gênero possuir folhas compostas, as mesmas foram fracionadas em pecíolo, nectário extrafloral (NEF), ráquis, peciólulo e foliólulos (Figura 2). As amostras anatômicas foram coletadas na região mediana destas frações.

Figura 2. Fracionamento realizado nas folhas de Desmanthus spp.

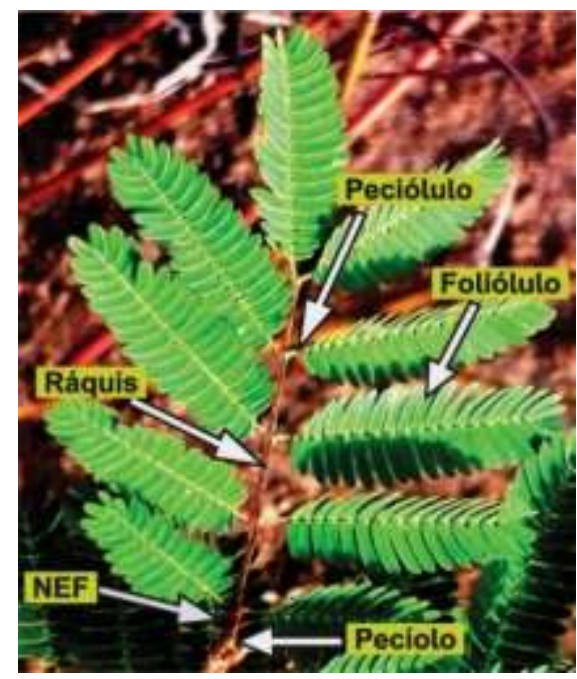

Fonte: Elaborado pelos autores.

Após o fracionamento, fixou-se a amostra em FAA $50 \%$ e $48 \mathrm{~h}$ depois foi realizada a transferência para solução estoque (álcool 70\%). No laboratório de botânica da Universidade Federal do Vale do São Francisco (UNIVASF), foi realizada a desidratação em série alcóolica e, em seguida, incluiu-se o material em historresina hidroxi-etil-metacrilato (LEICA ${ }^{\circledR}$ ).

As amostras foram então seccionadas em micrótomo rotativo Slee ${ }^{\circledR}$ (modelo CUT 5062), obtendo-se secções transversais de $5 \mu \mathrm{m}$. Os melhores cortes foram selecionados e corados com azul de toluidina, marcando-se histoquimicamente diferentes tecidos (O’Brien et al., 1964). Por fim, montaram-se lâminas permanentes com Entellan ${ }^{\circledR}$. Utilizou-se microscópio ótico com câmera acoplada para obtenção das imagens, usando o software TS View versão 6.2.4.5.

\section{Resultados e Discussão}

Foram encontradas cavidades secretoras no tecido floemático, exceto no foliólulo, e cristais prismáticos associados aos feixes vasculares em todos os genótipos e frações aqui estudadas. Da mesma maneira, foram observados compostos fenólicos na epiderme, colênquima e idioblastos nos tecidos avaliados. Assim, para evitar que a leitura se torne repetitiva a discussão destas características comum a todos será feita em um tópico a parte.

\subsection{Pecíolo}

A morfologia do pecíolo da folha 1 e 3 é diferente nos genótipos estudados. No genótipo 7G o pecíolo da folha 1 tem formato cilíndrico enquanto o da folha 3 tem projeções superiores (Figura 3A e 3D). O genótipo 50J apresenta, em ambas as folhas, morfologia circular do pecíolo (Figura 3B). A folha 1 do genótipo 13AU possui pecíolo com formato arredondado abaxialmente e projeções superiores (Figura 3C), enquanto a folha 3 deste genótipo tem formato cilíndrico (Figura 3D). Em todos os genótipos verificou-se a presença de colênquima abaixo da epiderme, com maior quantidade destas células nos pecíolos cilíndricos (Figuras 3B e 3D). Nota-se, ainda, a bainha esclerenquimática circundando os feixes vasculares nos genótipos com projeções superiores (Figura 3A e 3C). 
A morfologia dos pecíolos relatadas no presente trabalho são características da família Fabaceae e já foi verificado também em outras espécies desta família (Ferrarotto \& Jáuregui, 2008; Zamora-Natera \& Terrazas, 2012). Contudo, houve uma variação morfológica em folhas de diferentes idades podendo ter ocorrido como efeito inerente à espécie/genótipo, pois o pecíolo é um caractere de grande importância taxonômica por não sofrer alterações anatômicas em função das condições ambientais (Metcalfe \& Chalk, 1950).

Figura 3. Seções transversais dos pecíolos dos genótipos Desmanthus spp. A. Folha 3 do genótipo $7 \mathrm{G}$ com projeções superiores. B. Folha 1 do genótipo 50J de formato cilíndrico. C. Folha 1 do genótipo 13AU com projeções superiores. D. Folha 3 do genótipo 13AU com várias camadas de células no córtex. E. Cristais prismáticos, cavidades secretoras e raios parenquimáticos no tecido vascular. F. Parênquima cortical com detalhe na epiderme, tricoma e cristais prismáticos. $\mathrm{Ab}=$ superfície abaxial, $\mathrm{Ad}=$ superfície adaxial, $*$ = cavidade secretora, $\mathrm{C}=$ colênquima, $\mathrm{S}=$ esclerênquima, $\mathrm{FV}=$ feixe vascular, $\mathrm{Rp}=$ raios parenquimáticos, seta amarela $=$ drusa, seta preta $=$ cristais prismáticos, seta vermelha $=$ feixe vascular acessório, $\mathrm{Tr}=$ tricoma. Barras: $50 \mu \mathrm{m}(\mathrm{A}, \mathrm{B}, \mathrm{C}, \mathrm{D}), 10 \mu \mathrm{m}(\mathrm{E}, \mathrm{F})$.
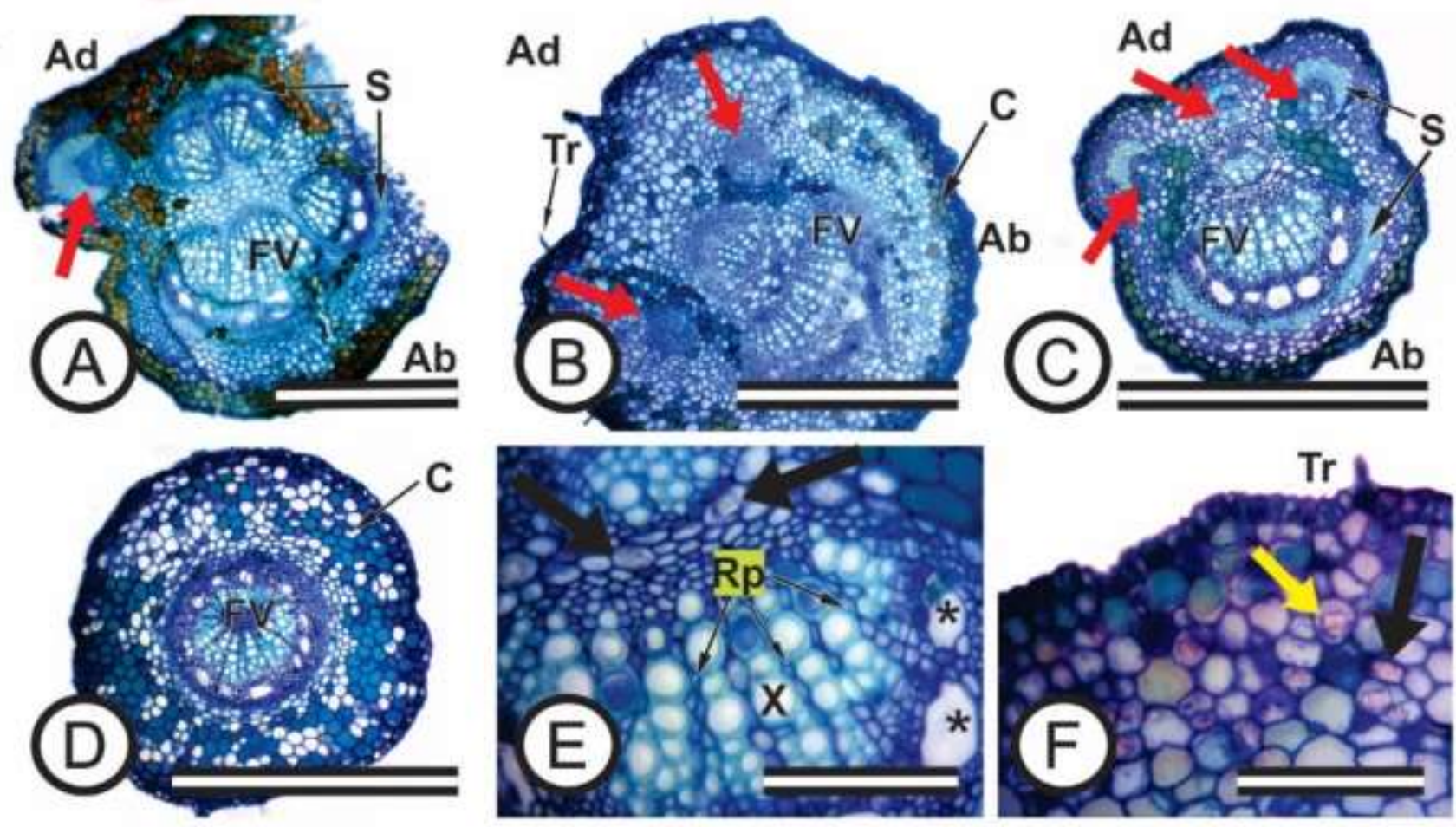

Fonte: Elaborado pelos autores.

É provável, ainda, que estas morfologias tenham diferido devido a funções mecânicas exercidas principalmente pelo colênquima, sendo um dos principais tecidos de sustentação do vegetal. As folhas em desenvolvimento que são submetidas à estresses bióticos e/ou abióticos tem aumentos na proporção deste tecido, situação em que as plantas avaliadas neste trabalho vinham sendo submetidas (cortes frequentes). Em contrapartida, a proporção de colênquima diminui à medida que há a formação do esclerênquima, pois é mais rígido devido ao espessamento e lignificação das paredes celulares, ocorrendo em órgãos mais velhos (Evert, 2006).

Os feixes vasculares ocorrem de 4 a 7 nos genótipos com projeções superiores, devido à vascularização acessória presente nas mesmas, observando-se um arco descontínuo nos feixes centrais (Figura 3A e 3C). Contrariamente, nos pecíolos de morfologia cilíndrica, há apenas um feixe central formando um anel contínuo (Figura 3D). As folhas 1 e 3 dos genótipos avaliados possuem feixes vasculares colaterais, com raios parenquimáticos no xilema e apresentam cavidades secretoras no tecido floemático (Figura 3E). 
O arranjo dos feixes vasculares no pecíolo já havia sido descrito por Metcalfe \& Chalk (1950) na família Fabaceae, no entanto, não haviam relatos na literatura com relação ao gênero Desmanthus e, principalmente, sobre a diferenciação morfológica que ocorre em folhas de diferentes idades. Com relação aos raios parenquimáticos nos pecíolos estudados, é possível inferir que a movimentação de água e nutrientes é intensa uma vez que estas células possuem alta atividade enzimática e liberam solutos no xilema. Desse modo, as plantas tornam a pressão mais negativa nos vasos condutores possibilitando maior absorção de água, característica importante para as plantas de clima semiárido (Brodersen et al., 2019).

Além disso, os raios parenquimáticos promovem uma continuidade do tecido vascular com o córtex, auxiliando nos fenômenos de movimentação foliar (nictinásticos). Assim, ocorrem alterações iônicas e no turgor das células do parênquima cortical em resposta às mudanças no padrão luminoso, resultando na movimentação das folhas/folíolos (Ferrarotto \& Jáuregui, 2008; Zamora-Natera \& Terrazas, 2012). Esta movimentação auxilia na economia de água na planta e também protege as folhas da radiação excessiva (Minorsky, 2019), pois as mesmas fecham-se em ciclos circadianos bem definidos como já descrito no gênero Desmanthus (Verloove \& Borges, 2018). Semelhantemente à Crotalaria juncea L. (Fabaceae) (Ferrarotto \& Jáuregui, 2008), acredita-se que as estruturas encontradas no pecíolo das espécies aqui estudadas são responsáveis pelos movimentos nictinásticos.

Umas das formas de atenuar a alta radiação solar e diminuir a temperatura das folhas é por meio dos tricomas, no entanto, estes foram encontrados apenas no genótipo 50J (Figura 3B, 3F). Estes apêndices epidérmicos atuam na reflexão da radiação solar e na formação de um microclima na superfície da folha, resultando na diminuição da taxa de transpiração e na manutenção de temperaturas menores (Evert, 2006).

\subsection{Nectário extrafloral}

A morfologia dos nectários extraflorais (NEFs) é similar entre os genótipos estudados, independentemente da idade, assemelhando-se ao formato de um cálice (Figura 4). Observa-se que o arranjo dos feixes vasculares dos NEF nos genótipos 7G e 50J são semelhantes (Figura 4A, 4B), enquanto o do 13AU difere dos mesmos (Figura 4C), onde os genótipos 7G e 50J apresentam cinco feixes localizados na região central da estrutura (Figura 4A). Contrariamente, o genótipo 13AU apresentou um feixe vascular centralizado e dois feixes vasculares acessórios (Figura 4C). Vale salientar que a folha 1 do genótipo 13AU apresentou 3 feixes vasculares acessórios.

Figura 4. Seções transversais dos nectários extraflorais dos genótipos de Desmanthus spp evidenciando epitélio secretor em formato de cálice. A. NEF do genótipo 7G. B. NEF do genótipo 50J. C. NEF do genótipo 13AU apresentando feixes vasculares acessórios. $\mathrm{Ab}=$ superfície abaxial, $\mathrm{Ad}=$ superfície adaxial, asterisco = cavidade secretora, $\mathrm{ES}=$ epitélio secretor, FV = feixe vascular, seta vermelha = feixe vascular acessório, $\mathrm{Tr}$ = tricoma. Barras: $50 \mu \mathrm{m}(\mathrm{A}, \mathrm{B}), 10 \mu \mathrm{m}(\mathrm{C})$.
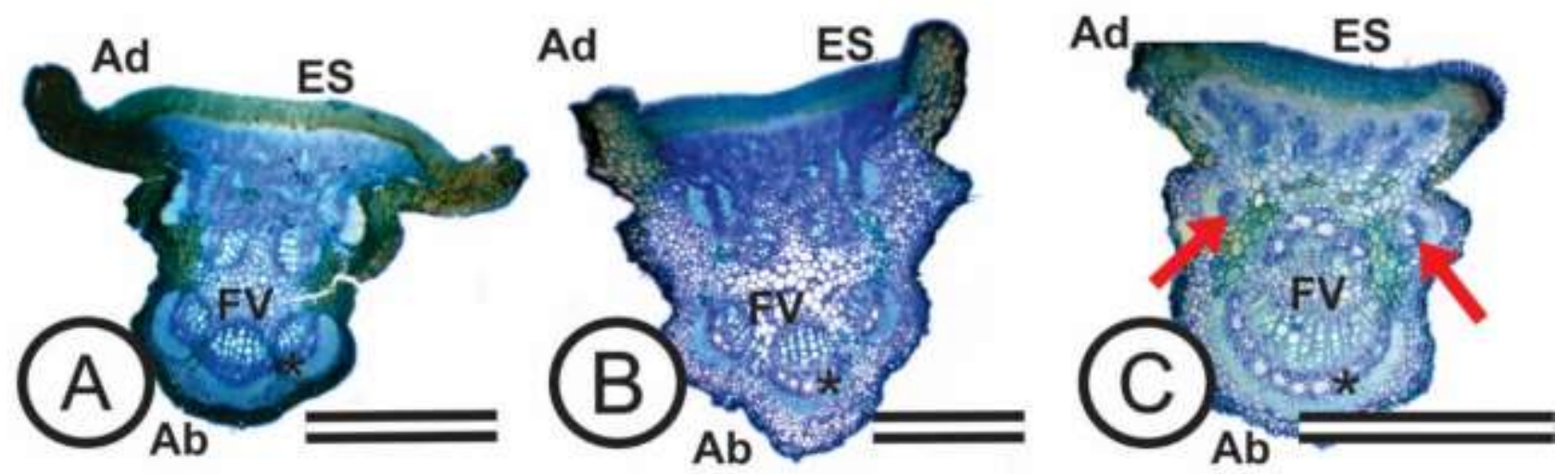

Fonte: Elaborado pelos autores. 
Observou-se em todos os genótipos a presença do tecido nectarífero na superfície adaxial da estrutura sendo composto por cutícula, uma camada de células epidérmicas de formato irregular e tricomas tectores unicelulares. Abaixo destas estruturas, encontram-se o parênquima nectarífero com aspecto paliçádico de tamanhos variados (Figura 5). Nota-se ainda uma grande vascularização do floema imediatamente abaixo do tecido nectarífero, o qual é rodeado por tecido parenquimático (subnectarífero) (Figura 5).

Figura 5. Detalhe do nectário extrafloral dos genótipos de Desmanthus spp. Seta = cutícula, Epi = epiderme, Tr $=$ tricomas, $\mathrm{TN}=$ tecido nectarífero com células de aspecto paliçádico, $\mathrm{Pa}=$ células parenquimáticas na zona de transição, $\mathrm{F}=$ vascularização floemática. Barra: $50 \mu \mathrm{m}$.

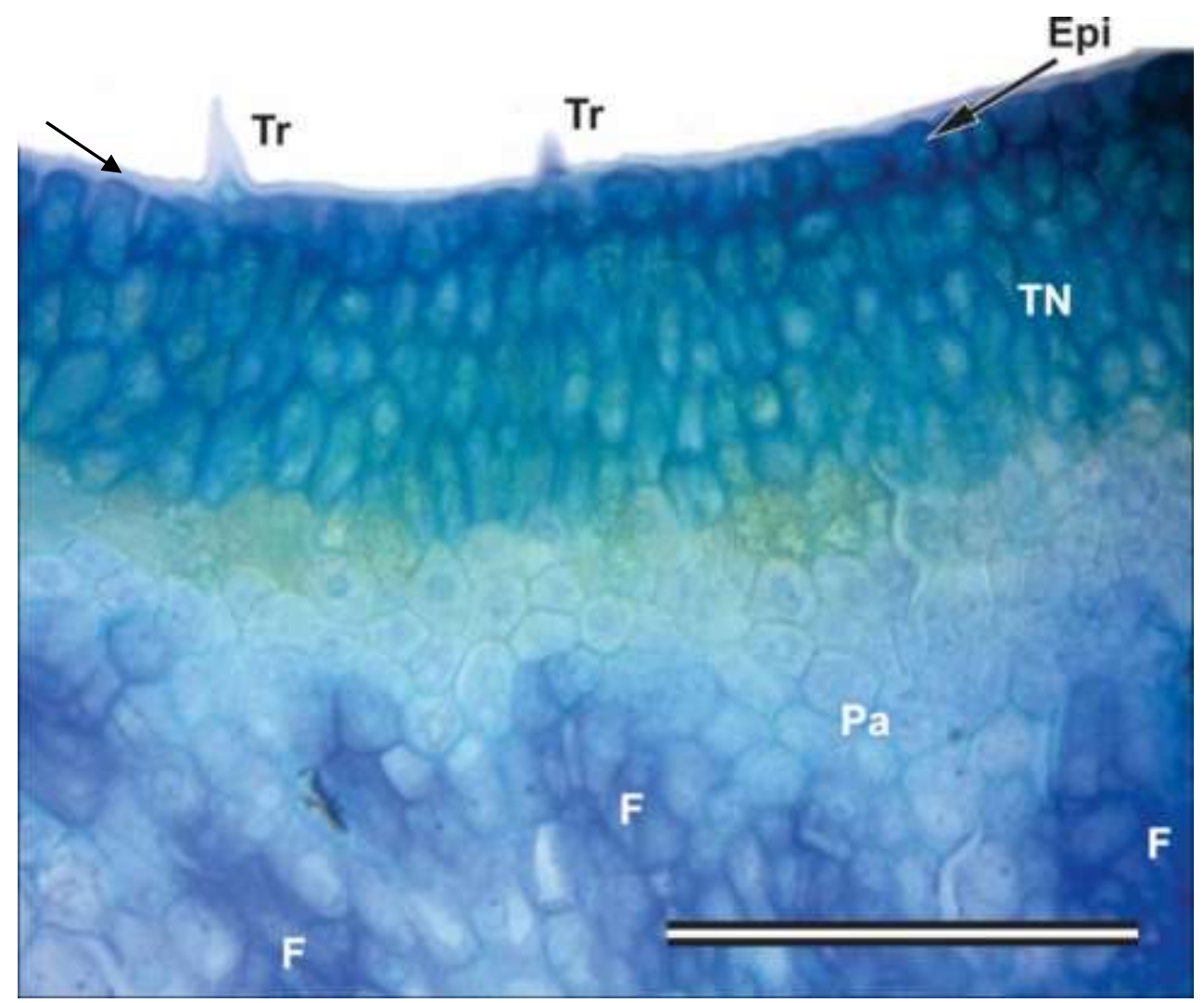

Fonte: Elaborado pelos autores.

A descrição anatômica dos NEFs no presente estudo estão em conformidade com González \& Marazzi (2018). Ainda de acordo com esses autores, os nectários consistem de uma estrutura bem organizada em que a epiderme modificada é a responsável pela liberação do néctar via rompimento cuticular. A presença de células parenquimáticas abaixo do tecido nectarífero marcam uma zona de transição entre a área vascularizada e não vascularizada, a qual é importante para evitar o fluxo apoplástico de substâncias para os tecidos internos, além de garantir o rápido fluxo de fotoassimilados, nutrientes e água, explicando assim a predominância de vasos floemáticos nessa região (González \& Marazzi, 2018).

O número de feixes vasculares e a presença de vascularização acessória no genótipo 13AU demonstra ser um caractere útil na diferenciação das espécies estudadas. A ocorrência de feixes vasculares acessórios no genótipo 13AU pode ser responsável, fisiologicamente, pelo maior suprimento de substâncias utilizadas na produção do néctar (Coutinho et al., 2012).

No momento da coleta foram observadas formigas visitando os NEFs, porém, as mesmas não foram coletadas para identificação. Como os NEFs ocorrem em órgãos vegetativos eles não tem relação com a polinização, mas são os responsáveis 
pela atração de formigas que protegem a planta contra herbívoros, onde a Myrmicaria brunnea Saunders é a principal espécie de formiga presente nas plantas do gênero Desmanthus (Nalini et al., 2019).

A secreção do néctar ocorre em maior quantidade pela manhã, diminuindo ao longo do dia e cessando durante a noite. Com isso, a visitação das formigas segue o mesmo ritmo, onde a máxima visitação ocorre pela manhã com redução drástica durante o dia e ausência das mesmas durante a noite (González \& Marazzi, 2018; Nalini et al., 2019).

\subsection{Ráquis}

As ráquis dos genótipos $7 \mathrm{G}$ e 50J têm formato côncavo-convexo, independentemente da idade da folha, apresentando projeções superiores com feixes vasculares (Figura 6A e B). O genótipo 13AU apresenta um formato próximo do cilíndrico (Figura 6C).

Verifica-se nos genótipos 7G e 50J uma epiderme de aspecto comum (Figura 6F), enquanto no 13AU a mesma tem aspecto papiloso, especialmente na superfície abaxial (Figura 6E). Não foram observados tricomas em nenhuma das ráquis avaliadas.

Todos os feixes vasculares avaliados são colaterais. Os genótipos $7 \mathrm{G}$ e 50J contam com 2-4 feixes vasculares no centro da estrutura e um feixe acessório em cada uma das projeções superiores (Figura 6A e B), os quais possuem cavidades secretoras (Figura 6D). Diferentemente, o genótipo 13AU apresenta apenas um feixe centralizado, com cavidades secretoras volumosas no floema (Figura 6C). Verifica-se o desenvolvimento do tecido vascular nas folhas jovens avaliadas, onde observa-se claramente o tamanho dos vasos xilemáticos e o procâmbio (Figura 6D e E).

Em todos os genótipos avaliados nota-se a presença de uma bainha esclerenquimática bem definida em torno dos feixes

Figura 6. Seções transversais das ráquis dos genótipos de Desmanthus spp. A. Ráquis do genótipo 7G e do B. genótipo 50J com formato côncavo-convexo. C. Ráquis do genótipo 13AU com formato cilíndrico. D. Detalhe do feixe vascular em desenvolvimento na folha 1 , com pequenos vasos do xilema, procâmbio evidente e cavidades secretoras no tecido floemático. E. Destaque na epiderme com aspecto papiloso, zona procambial, vasos xilemáticos mais desenvolvidos e cavidades secretoras volumosas e de formato irregular na folha 3. F. Detalhe na epiderme de aspecto comum, cavidades secretoras e bainha esclerenquimática no feixe vascular acessório da ráquis. $\mathrm{Ab}=$ superfície abaxial, $\mathrm{Ad}=$ superfície adaxial, * = cavidade secretora, Epi $=$ epiderme, $\mathrm{Fl}=$ floema, $\mathrm{FV}=$ feixe vascular, $\mathrm{P}=$ procâmbio, $\mathrm{S}=$ esclerênquima, seta preta $=$ cristal prismático, seta vermelha $=$ feixe vascular acessório, $\mathrm{Xi}=$ xilema. Barras: $50 \mu \mathrm{m}(\mathrm{A}), 20 \mu \mathrm{m}(\mathrm{B}, \mathrm{C}), 10 \mu \mathrm{m}$
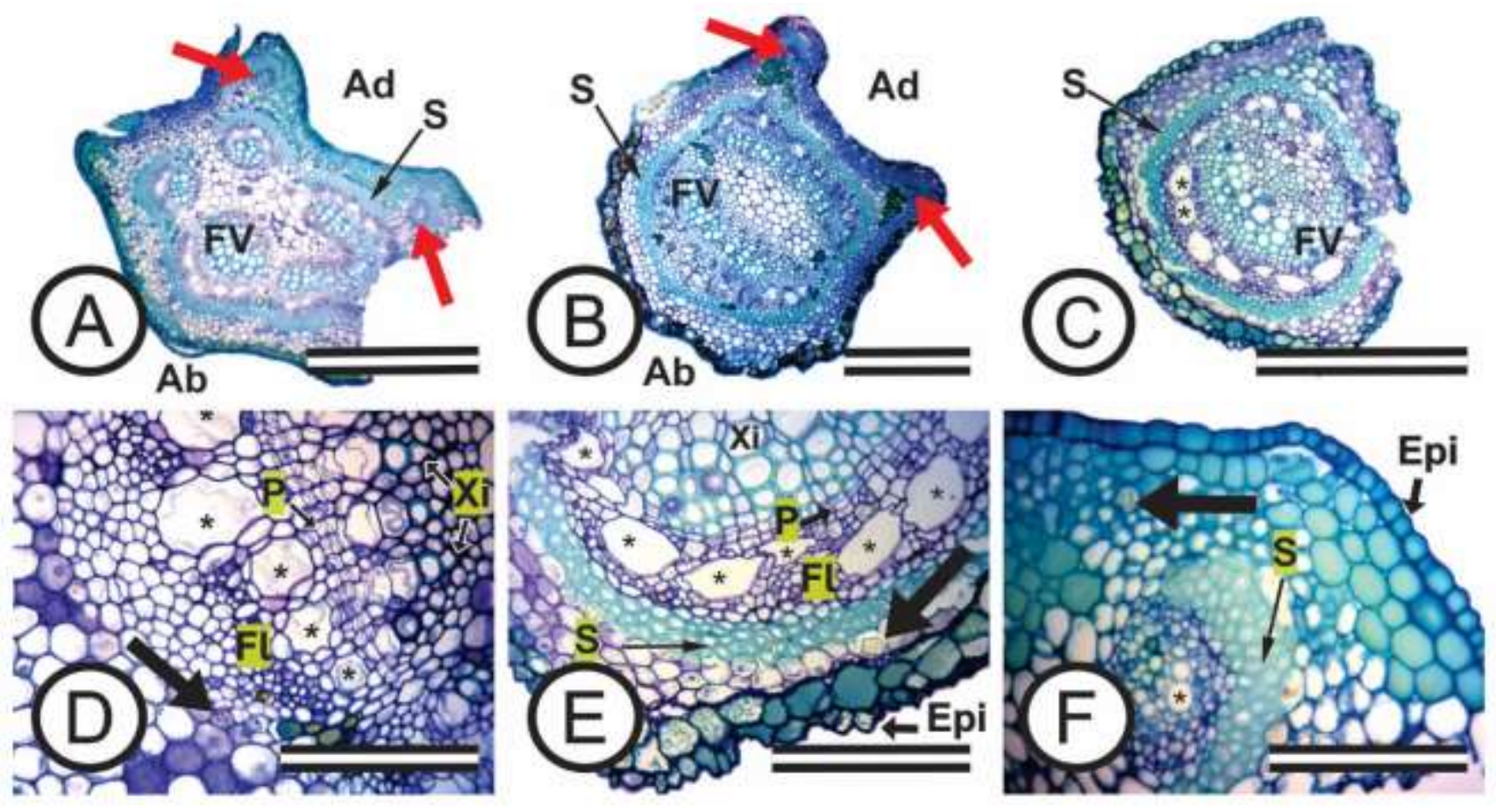

Fonte: Elaborado pelos autores. 
vasculares (Figura 6A, B e C), característica que já foi relatada por outros autores estudando espécies da família Fabaceae (Ló \& Duarte, 2011). Esta característica proporciona maior resistência mecânica para sustentar a folha devido a sua lignificação, de forma que os folíolos possam interceptar a luz solar (Zorić et al., 2014). Observa-se no genótipo 13AU uma camada de células colenquimatosas imediatamente abaixo da epiderme na face abaxial (Figura 6E). Estas células asseguram também a rigidez da estrutura, pois, apesar de não haver lignificação da parede celular, ocorre um espessamento da mesma (Zorić et al., 2014).

\subsection{Peciólulo}

A morfologia do peciólulo nos três genótipos é similar, onde a porção abaxial é arredondada (em formato de U) e a porção adaxial apresenta projeções (Figura 7). Nota-se que a epiderme é comum nos genótipos 7G e 50J (Figura 7A), sendo papilosa apenas no genótipo 13AU (Figura 7B). Existe uma camada de células colenquimatosas adjacentes a epiderme na face abaxial de grande volume em todos os genótipos (Figura 7A e B). Apenas no genótipo 13AU observam-se células esclerenquimáticas circundando o feixe vascular central (Figura 7B), característica que pode ser utilizada na diferenciação das espécies, pois independentemente da idade das folhas avaliadas, tal estrutura demonstra ser presente no genótipo 13AU ( $D$. virgatus) e ausente nos genótipos 7G e 50J (D. pernambucanus).

Figura 7. Seções transversais dos peciólulos dos genótipos de Desmanthus spp.

A. Representação do peciólulo nos genótipos $7 \mathrm{G}$ e $50 \mathrm{~J}$, com epiderme de aspecto comum e células colenquimatosas de grande volume adjacente à epiderme. B. Peciólulo do genótipo 13AU com epiderme de aspecto papiloso, células colenquimatosas junto à epiderme e feixe vascular acessório circundado por células esclerenquimáticas. C. Destaque nos feixes vasculares principal e acessório, evidenciando a presença de cristais prismáticos, procâmbio e idioblastos ricos em compostos fenólicos. Asterisco = cavidade secretora, $\mathrm{Ab}=$ superfície abaxial, $\mathrm{Ad}=$ superfície adaxial, Epi $=$ epiderme, $\mathrm{Fl}=$ floema, $\mathrm{FV}=$ feixe vascular, seta preta $=$ cristal prismático, seta vermelha $=$ feixe vascular acessório, $\mathrm{P}=$ procâmbio, $\mathrm{S}=$ esclerênquima, $\mathrm{Xi}=$ xilema. Barras: $20 \mu \mathrm{m}(\mathrm{A}, \mathrm{B}), 10 \mu \mathrm{m}(\mathrm{C})$.
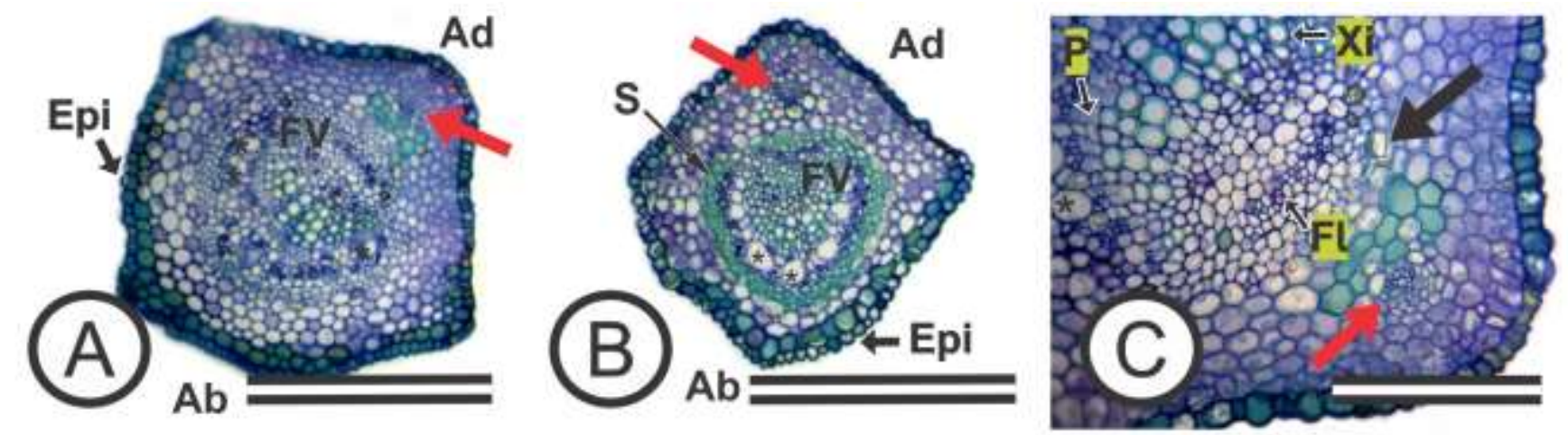

Fonte: Elaborado pelos autores.

Existem dois feixes vasculares nos peciólulos estudados, sendo um principal, localizado no centro da estrutura e um feixe acessório na projeção adaxial (Figura 7A e 7B). Imediatamente abaixo do feixe acessório encontram-se numerosos idioblastos ricos em compostos fenólicos nos acessos 7G e 50J (Figura 7C). Nota-se a presença do procâmbio próximo dos vasos xilemáticos, indicando o desenvolvimento do tecido vascular na folha jovem.

As folhas do gênero Desmanthus são do tipo compostas (Figura 2), significando dizer que o folíolo possui um eixo central (peciólulo) onde os foliólulos se inserem. Levando este fato em consideração, é razoável admitir que os movimentos nictinásticos (foliares) presente nas espécies aqui estudadas são promovidos pelo peciólulo. Estes movimentos são fenômenos conhecidos nos vegetais e respondem a estímulos luminosos, dirigidos pelo fitocromo. A movimentação ocorre em função de 
alterações no turgor de células motoras, onde o fitocromo altera o comportamento das membranas celulares promovendo o fluxo de $\mathrm{K}^{+}$e $\mathrm{Cl}^{-}$para dentro e fora das células motoras (Minorsky, 2019).

Desse modo, as plantas identificam as alterações no padrão luminoso por meio da captação de diferentes comprimentos de onda, em que a luz vermelha estimula a abertura dos folíolos e a luz vermelho distante estimula seu fechamento. Consequentemente, durante o dia a abertura dos folíolos se dá pela maior proporção vermelho:vermelho distante e no final da tarde esta razão diminui severamente, devido a maior proporção da luz vermelho distante (Minorsky, 2019).

Por conta dessa movimentação, é provável que a camada de colênquima adjacente à epiderme abaxial proporcione a resistência mecânica da estrutura, devido ao espessamento de sua parede celular (Zorić et al., 2014).

\subsection{Foliólulo}

Em todos os genótipos estudados existe uma epiderme uni seriada com formato variando de tabular à oval e paredes periclinais sinuosas (Figura 8). Não foram observados tricomas em nenhum dos genótipos. Nos genótipos 7G e 50J é possível observar que o mesofilo da folha 1 é homogêneo e possui quatro camadas de células ovais e irregulares, aumentando o número de camadas à medida que se aproxima da nervura principal (Figura 8A).

Figura 8. Seções transversais dos foliólulos dos genótipos de Desmanthus spp. A. Mesofilo homogêneo na folha 1 dos genótipos 7G e 50J na região do feixe vascular principal. B. Mesofilo dorsiventral na região do feixe vascular de maior calibre, com destaque no parênquima paliçádico, lacunoso e na bainha vascular. C. Feixe vascular de pequeno calibre no mesofilo, com destaque no cristal prismático em célula da bainha vascular e câmaras subestomáticas na superfície adaxial e abaxial. $\mathrm{Ab}=$ superfície abaxial, $\mathrm{Ad}=$ superfície adaxial, $\mathrm{cs}=$ câmara subestomática, $\mathrm{Fl}=$ floema, $\mathrm{PL}=$ parênquima lacunoso, $\mathrm{PP}=$ parênquima paliçádico, seta preta $=$ cristal prismático, $\mathrm{Xi}=$ xilema. Barras: $10 \mu \mathrm{m}$.
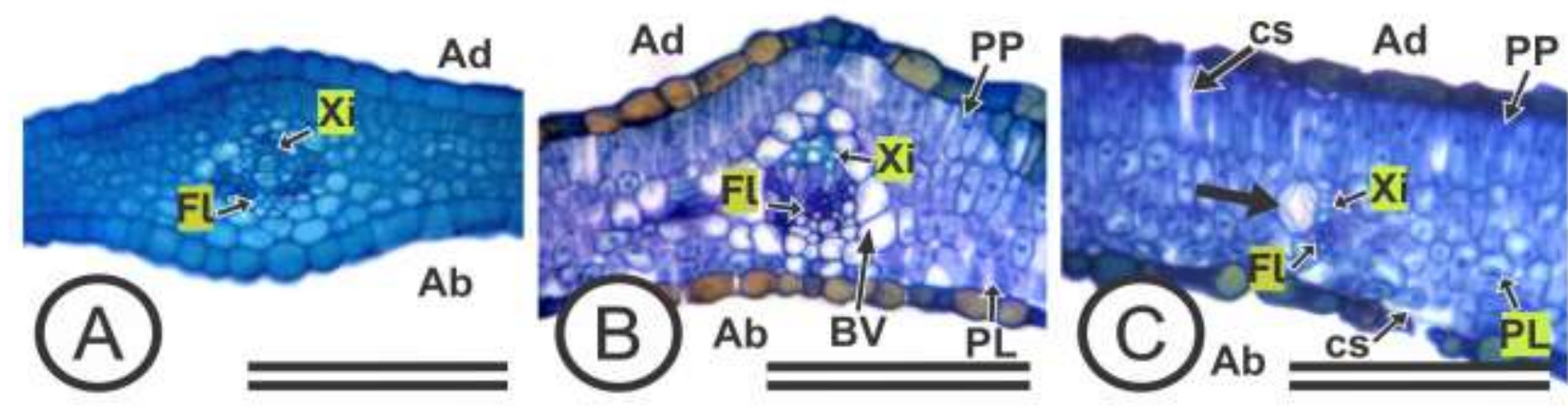

Fonte: Elaborado pelos autores.

Diferentemente, o genótipo 13AU apresentou mesofilo dorsiventral, ou seja, com parênquima paliçádico e lacunoso em ambas as folhas, característica também observada na folha 3 dos demais genótipos (Figura 8B). Nas folhas de mesofilo dorsiventral (folha 3 dos genótipos 7G e 50J e em ambas do 13AU) verifica-se uma camada de células paliçádicas internamente à face adaxial da epiderme, apresentando-se compactadas, alongadas e isodiamétricas. O parênquima lacunoso ocorre imediatamente abaixo deste, com 2-5 camadas de células pequenas, com formato irregular, apresentando alguns espaços intercelulares e câmaras subestomáticas (Figura 8B e C).

Nota-se ainda a ocorrência de estômatos em ambas as faces da folha 3, sendo de maior tamanho na face abaxial (Figura 8C). Em todos os genótipos estudados ocorrem feixes vasculares de diferentes calibres ao longo do mesofilo (Figura 8C). Em torno dos feixes vasculares de maior calibre a presença de bainha vascular é notória (Figura 8B) e, no caso do genótipo 50J e 13AU, ocorreram cristais prismáticos na bainha vascular (Figura 8C). 
O mesofilo dorsiventral é uma característica comum à várias famílias do reino vegetal, inclusive na Fabaceae (Metcalfe \& Chalk, 1950). O aspecto compacto do parênquima paliçádico demonstra a adaptação destas plantas à condição semiárida, pois possibilita o máximo aproveitamento da radiação incidente e minimiza a perda de água em situações de déficit hídrico, impedindo que haja uma murcha rápida, principalmente em folhas sem tricomas (Ren et al., 2019).

Nas folhas jovens dos genótipos 7G e 50J não foi possível diferenciar o tecido paliçádico do lacunoso, certamente, por não terem atingido sua maturidade. Corroborando com isso, De Oliveira \& Isaías (2009) avaliando a Copaifera langsdorffii (Fabaceae) relataram que as folhas jovens desta planta apresentaram mesofilo homogêneo, enquanto as folhas adultas diferenciavam-se e constituíam o mesofilo dorsiventral.

Esta característica ainda não havia sido descrita para o gênero Desmanthus, porém, apenas a espécie $D$. pernambucanus apresentou diferentes arranjos do mesofilo nas idades avaliadas (genótipo 7G e 50J). Não obstante, a $D$. virgatus (genótipo 13AU) demonstrou diferenciar precocemente o mesofilo. Com base nestas observações, salienta-se que tal descrição pode ser útil na diferenciação dessas espécies.

Com relação aos espaços intercelulares observados, destaca-se a importância dos mesmos para a planta, pois aumentam a superfície de contato das células e facilita as trocas gasosas para que haja assimilação do $\mathrm{CO}_{2}$ atmosférico (Ren $e t$ al., 2019). Ao se pensar na utilização destas folhas como alimento para os animais, os estômatos e espaços intercelulares são a principal porta de entrada para os microrganismos colonizarem e degradarem os tecidos (De Franca et al., 2010), principalmente porque os tecidos presentes nas folhas não apresentam crescimento secundário da parede celular e são ricas em conteúdo solúvel resultando em rápida degradação (Zorić et al., 2014).

\subsection{Cavidades secretoras}

As cavidades secretoras foram observadas na região do floema em todos os tecidos aqui avaliados, independentemente da idade, com exceção dos foliólulos. Estas cavidades apresentam lume com tamanho e formato variável, sendo elíptico e/ou com paredes sinuosas (Figura 3C, 3E, 4A, 4C, 6D, 6E, 7B). A formação das cavidades secretoras se dá por diferentes formas, mas na família Fabaceae ocorre pelo modo esquizogênico, onde células vizinhas se separam resultando na formação de um espaço (lúmen) dotado de epitélio secretor (Fahn, 2004).

Assim, há liberação de diversas substancias no lúmen como terpenóides, taninos, óleos, resinas, polissacarídeos, sendo secretados puros ou em mistura (Evert, 2006). Apesar desta grande variedade de compostos, não se sabe qual o material secretado pelo gênero Desmanthus, pois em testes histoquímicos realizados não se detectou a presença de alcalóides, lactonas sesquiterpênicas e taninos condensados (dados não publicados).

Alguns gêneros da subfamília Mimosaceae, que inclui o gênero Desmanthus, apresentam cavidades secretoras no tecido floemático a exemplo da Acacia, Inga, Mimosa e Pithecolombium (Metcalfe \& Chalk, 1950). Já algumas espécies da subfamília Papilionoidae apresentam cavidades no córtex do pecíolo, ráquis e na nervura central do folíolo (Palermo et al., 2017), enquanto outras apresentam no tecido floemático (Da Silva et al., 2013). Assim, a ocorrência destas estruturas é comum na família Fabaceae e permite uma identificação genérica desta família e, consequentemente, um diagnóstico da espécie, pois os relatos para o gênero Desmanthus na literatura são incipientes.

Ecologicamente, as substâncias secretadas pelas cavidades atuam principalmente na proteção contra herbívoros e patógenos, atuando como dissuasivos alimentares (Fahn, 2004). Nesse sentido, é razoável considerar que a não identificação das substâncias nas cavidades secretoras no presente trabalho relacione-se com (i) a ocorrência de substâncias não testadas ou (ii) a inibição da resposta vegetal aos danos causados no momento da coleta, pois ao utilizar o fixador FAA as atividades enzimáticas são inativadas. 
Com relação à histo-localização das cavidades secretoras no presente trabalho, pode-se considerar uma estratégia importante para a ecofisiologia da planta, pois sua ocorrência no tecido floemático possibilita o transporte de substâncias no sentido folha-raiz. Apesar disso, são necessários mais estudos para identificar quais substâncias são produzidas como também investigar a fundo as funções desempenhadas neste gênero.

\subsection{Cristais prismáticos}

Foram detectados cristais prismáticos em todos os genótipos e frações, ocorrendo em associação aos feixes vasculares, no parênquima medular e cortical (Figura 3E, 3F, 6D, 6E, 7C). Nos pecíolos mais maduros houve ocorrência de drusas apenas nos genótipos 7G e 50J (Figura 3F). Nos foliólulos foram detectados cristais na bainha vascular dos genótipos 50J e 13AU, em ambas as folhas (Figura 8C). Estes cristais são compostos por oxalato de cálcio e a presença de diferentes tipos numa mesma espécie já foi descrito (Metcalfe \& Chalk, 1950).

A formação dos cristais de oxalato de cálcio se dão por diferentes vias metabólicas e por muito tempo mostrou-se a importância dos mesmos na regulação do metabolismo mineral atuando no balanço de íons, regulação do conteúdo endógeno de cálcio $\left(\mathrm{Ca}^{2+}\right)$, suporte mecânico (rigidez), reflexão da luz, transdução de sinais na célula e servindo como reserva de cálcio em situações de necessidade (Cuéllar-Cruz et al., 2020; He et al., 2014).

Tooulakou et al. (2016) demonstrou que os cristais tem uma rápida formação e degradação, com ciclos circadianos bem definidos, onde à noite o conteúdo dos cristais é aumentado (volume e quantidade) e durante o dia sofre uma redução. Por meio da ação da enzima oxalato oxidase há a conversão do oxalato em $\mathrm{CO}_{2}$ quando a planta se encontra em déficit hídrico, situação na qual a entrada de $\mathrm{CO}_{2}$ via estômatos é limitada ou inexistente. Assim, os autores comprovaram que o oxalato se torna uma fonte endógena de carbono para as reações fotossintéticas.

A ocorrência de cristais associados aos feixes vasculares no presente trabalho demonstra que possivelmente há a degradação dos mesmos proporcionando um fluxo de oxalato para os folíolos, via xilema, como também para o clorênquima. Além disso, a absorção de $\mathrm{Ca}^{2+}$ se dá pelas raízes e o transporte é realizado pelo tecido vascular, sugerindo que há também ajustes do conteúdo mineral da planta ao longo deste caminho como também os idioblastos tem uma capacidade máxima em estocar cristais, induzindo as células vizinhas a acumularem o $\mathrm{Ca}^{2+}$ (Cuéllar-Cruz et al., 2020). Estes fenômenos explicam a vasta ocorrência dos cristais nas estruturas aqui estudadas.

Ao avaliar diferentes grupos funcionais $\left(\mathrm{C}_{3}, \mathrm{C}_{4}\right.$ e $\left.\mathrm{CAM}\right)$ Tooulakou et al. (2016) verificaram que a degradação dos cristais ocorreu em todos eles e sugeriram que nas plantas xerófitas esta característica tende a ser maior, em função da susceptibilidade contínua ao déficit hídrico. Desse modo, de acordo com os autores, a presença de cristais em tecidos vegetais possibilita que (i) as plantas tenham maior economia de água e, nas plantas xerófitas, possibilita maior resistência à seca; (ii) diminui o risco de fotoinibição devido à atividade fotossintética continuar na condição de déficit hídrico, mesmo que em níveis basais e também (iii) benefícios metabólicos, pois os cristais são elementos metabolicamente e osmoticamente inativos sendo degradados e utilizados apenas em casos de necessidade.

\subsection{Compostos fenólicos}

Ao utilizar o corante azul de toluidina, que também é um marcador histoquímico, os compostos fenólicos apresentam a cor verde ou azul-esverdeada (O’Brien et al., 1964). Assim, foi possível observar no córtex dos pecíolos e no tecido colenquimatoso adjacente à epiderme do pecíolo (Figuras 3B, 3D, 3F), NEF (Figura 4), ráquis (Figuras 6E, 6F) e peciólulo (Figura 7) numerosos idioblastos ricos em compostos fenólicos. Tal característica se dá, no córtex dos pecíolos, por conta da relação destes compostos com os movimentos nictinásticos, pois, funcionalmente, eles auxiliam no acúmulo e liberação de íons (Minorsky, 2019). 
Além disso, as plantas da Caatinga são submetidas a altas temperaturas e radiação solar assim como longos períodos de seca, ocorrendo frequentemente a fotoinibição devido a limitações no fornecimento de $\mathrm{CO}_{2}$ via estomática. Desse modo, a energia não utilizada nas reações fotossintéticas reage com o oxigênio molecular presente nos cloroplastos e gera, por sua vez, espécies reativas de oxigênio. Para atenuar os efeitos deletérios do estresse oxidativo a planta conta com agentes antioxidantes, como os compostos fenólicos (Falcioni et al., 2020).

A presença de compostos fenólicos nas células do colênquima e da epiderme são uma forma de proteção para as plantas, pois conferem imunidade à microrganismos patogênicos e também atuam como dissuasivos alimentares, principalmente quando as plantas são usadas em dietas para ruminantes o que impede a colonização microbiana (De Franca $e t$ al., 2010). Considera-se ainda que os compostos fenólicos são capazes de reduzir a passagem de luz pelas células epidérmicas, principalmente em plantas xerófilas, protegendo contra o excesso de luminosidade e os danos da radiação ultravioleta A e B (Falcioni et al., 2020; Ren et al., 2019).

\section{Conclusão}

Existem diferenças anatômicas nas frações avaliadas com relação às diferentes idades, principalmente no pecíolo e ráquis, sendo isso relatado de forma inédita para o gênero Desmanthus. Paralelamente, há uma maior similaridade dos caracteres avaliados nos genótipos da espécie D. pernambucanus ( $7 \mathrm{G}$ e 50J) se comparados ao genótipo da espécie $D$. virgatus (13AU), indicando uma potencial caracterização taxonômica. Com isso, faz-se necessário aprofundar os estudos de forma que se possa caracterizar qual o exsudato produzido pelas cavidades secretoras.

\section{Agradecimentos}

Esse trabalho foi conduzido com auxílio da bolsa de estudos fornecida pela Coordenação de Aperfeiçoamento de Pessoal de Nível Superior - Brasil (CAPES) ao primeiro autor.

\section{Referências}

Alvares, C. A., Stape, J. L., Sentelhas, P. C., De Moraes Gonçalves, J. L., \& Sparovek, G. (2013). Köppen’s climate classification map for Brazil. Meteorologische Zeitschrift, 22(6), 711-728. https://doi.org/10.1127/0941-2948/2013/0507

Brodersen, C. R., Roddy, A. B., Wason, J. W., \& McElrone, A. J. (2019). Functional Status of Xylem Through Time. Annual Review of Plant Biology, 70 , 407-433. https://doi.org/10.1146/annurev-arplant-050718-100455

Calado, T. B., Cunha, M. V, Teixeira, V. I., Dos Santos, M. V. F., Cavalcanti, H. S., \& Lira, C. C. (2016). Morphology And Productivity Of “ Jureminha” Genotypes ( Desmanthus spp . ) Under Different Cutting Intensities 1. Revista Caatinga, 29(3), 742-752.

Costa, J. C., Fracetto, G. G. M., Fracetto, F. J. C., Santos, M. V. F., \& Lira Júnio, M. A. (2017). Genetic diversity of Desmanthus sp accessions using ISSR markers and morphological traits. Genetics and Molecular Research, 16(2).

Coutinho, Í. A. C., Francino, D. M. T., Azevedo, A. A., \& Meira, R. M. S. A. (2012). Anatomy of the extrafloral nectaries in species of Chamaecrista section Absus subsection Baseophyllum (Leguminosae, Caesalpinioideae). Flora: Morphology, Distribution, Functional Ecology of Plants, $207(6), 427-435$. https://doi.org/10.1016/j.flora.2012.03.007

Cuéllar-Cruz, M., Pérez, K. S., Mendoza, M. E., \& Moreno, A. (2020). Biocrystals in plants: A short review on biomineralization processes and the role of phototropins into the uptake of calcium. Crystals, 10(7), 1-23. https://doi.org/10.3390/cryst10070591

da Silva, M. A., dos Santos, M. V. F., Lira, M. de A., Dubeux Júnior, J. C. B., de Andrade Silva, D. K., Santoro, K. R., de Arruda Leite, P. M. B., \& de Freitas, E. V. (2012). Qualitative and anatomical characteristics of tree-shrub legumes in the forest zone in Pernambuco state, Brazil. Revista Brasileira de Zootecnia, 41(12), 2396-2404. https://doi.org/10.1590/S1516-35982012001200003

da Silva, M. M. B., Santana, A. S. C. O., Pimentel, R. M. M., Silva, F. C. L., Randau, K. P., \& Soares, L. A. L. (2013). Anatomy of leaf and stem of Erythrina velutina. Brazilian Journal of Pharmacognosy, 23(2), 200-206. https://doi.org/10.1590/S0102-695X2013005000013

De Franca, A. A., Guim, A., Batista, Â. M. V., De Mendonça Pimentel, R. M., Ferreira, G. D. G., \& Martins, I. D. S. L. (2010). Anatomia e cinética de degradação do feno de Manihot glaziovii. Acta Scientiarum - Animal Sciences, 32(2), 131-138. https://doi.org/10.4025/actascianimsci.v32i2.8800

de Oliveira, D. C., \& Isaias, R. M. dos S. (2009). Influence of leaflet age in anatomy and possible adaptive values of the midrib gall of Copaifera langsdorffii (Fabaceae: Caesalpinioideae). Revista de Biologia Tropical, 57(1-2), 293-302. 
Erbano, M., \& Duarte, M. R. (2008). Centrolobium tomentosum: macro- and microscopic diagnosis of the leaf and stem. Brazilian Journal of Pharmacognosy, 22(2), 249-256.

EVERT, R. F. (2006). Esau's plant anatomy: meristems, cells, and tissues of the plant body: their structure, function, and development (3rd ed.). John Wiley \& Sons. https://doi.org/10.1002/0470047380

FAHN, A. (2004). Functions and location of secretory tissues in plants and their possible evolutionary trends. Israel Journal of Plant Sciences, 50(1), 0-0. https://doi.org/10.1560/ljut-m857-tcb6-3fx5

Falcioni, R., Moriwaki, T., Pattaro, M., Herrig Furlanetto, R., Nanni, M. R., \& Camargos Antunes, W. (2020). High resolution leaf spectral signature as a tool for foliar pigment estimation displaying potential for species differentiation. Journal of Plant Physiology, 249(October 2019), 153161. https://doi.org/10.1016/j.jplph.2020.153161

Ferrarotto, M., \& Jáuregui, D. (2008). Relación entre aspectos anatómicos del pecíolo de Crotalaria juncea L. (Fabaceae) y el movimiento nástico foliar. Polibotánica, 26, 127-136.

Gonzalez, A. M., \& Marazzi, B. (2018). Extrafloral nectaries in Fabaceae: Filling gaps in structural and anatomical diversity in the family. Botanical Journal of the Linnean Society, 187(1), 26-45. https://doi.org/10.1093/botlinnean/boy004

He, H., Veneklaas, E. J., Kuo, J., \& Lambers, H. (2014). Physiological and ecological significance of biomineralization in plants. Trends in Plant Science, 19(3), 166-174. https://doi.org/10.1016/j.tplants.2013.11.002

Ló, S. M. S., \& Duarte, M. R. (2011). Morpho-anatomical study of the leaf and stem of pau-alecrim: Holocalyx balansae. Brazilian Journal of Pharmacognosy, 21(1), 4-10. https://doi.org/10.1590/S0102-695X2011005000015

Metcalfe, C. R., \& Chalk, L. (1950). Anatomy of the Dicotyledons (M. M. Chattaway, C. L. Hare, F. R. Richardson, \& E. M. Slatter (eds.)). Oxford University Press.

Minorsky, P. V. (2019). The functions of foliar nyctinasty: a review and hypothesis. Biological Reviews, 94(1), 216-229. https://doi.org/10.1111/brv.12444

Muir, J. P., \& Pitman, W. D. (1991). Responses of Desmanthus virgatus, Desmodium heterocarpon and Galactia elliotii to defoliation. Tropical Grasslands, $25,291-296$.

Nalini, T., Jayanthi, R., \& Selvamuthukumaran, T. (2019). Studies on morphology, distribution of EFNs and the associationofantswithextrafloralnectariesbearing plants. Plant Archives, 19(1), 1699-1710.

O’Brien, T. P., Feder, N., \& McCully, M. E. (1964). Polychromatic staining of plant cell walls by toluidine blue O. Protoplasma, 59(2), 368-373. https://doi.org/10.1007/BF01248568

Palermo, F. H., Teixeira, S. de P., Mansano, V. de F., Leite, V. G., \& Rodrigues, T. M. (2017). Secretory spaces in species of the clade Dipterygeae (Leguminosae, Papilionoideae). Acta Botanica Brasilica, 31(3), 374-381. https://doi.org/10.1590/0102-33062016abb0251

Pengelly, B. C., \& Liu, C. J. (2001). Genetic relationships and variation in the tropical mimosoid legume Desmanthus assessed by random amplified polymorphic DNA. 1993, 91-99.

Ren, T., Weraduwage, S. M., \& Sharkey, T. D. (2019). Prospects for enhancing leaf photosynthetic capacity by manipulating mesophyll cell morphology. Journal of Experimental Botany, 70(4), 1153-1165. https://doi.org/10.1093/jxb/ery448

Taiz, L., \& Zeiger, E. (2007). Fisiologia vegetal (Vol. 10). Universitat Jaume I.

Tooulakou, G., Giannopoulos, A., Nikolopoulos, D., Bresta, P., Dotsika, E., Orkoula, M. G., Kontoyiannis, C. G., Fasseas, C., Liakopoulos, G., Klapa, M. I., \& Karabourniotis, G. (2016). "Alarm photosynthesis": calcium oxalate crystals as an internal CO2 source in plants. Plant Physiology, 171(August), pp.00111.2016. https://doi.org/10.1104/pp.16.00111

Verloove, F., \& Borges, L. M. (2018). On the identity and status of Desmanthus ( Leguminosae, Mimosoid clade ) in Macaronesia. Collectanea Botanica, $37(7), 1-10$.

Zamora-Natera, J. F., \& Terrazas, T. (2012). Anatomía foliar y del pecíolo de cuatro especies de Lupinus (Fabaceae). Revista Mexicana de Biodiversidad, 83(3), 687-697. https://doi.org/10.7550/rmb.27264

Zorić, L., Mikić, A., Ćupina, B., Luković, J., Krstić, D., \& Antanasović, S. (2014). Digestibility-related histological attributes of vegetative organs of barrel medic (Medicago truncatula Gaertn.) cultivars. Zemdirbyste, 101(3), 257-264. https://doi.org/10.13080/z-a.2014.101.033 